\title{
水素容器
}

Journal of The Japan Institute of Light Metals, Vol. 67, No. 7 (2017), 301-306 (C) 2017 The Japan Institute of Light Metals

\section{Hydrogen cylinders}

Senta TOJO*

Keywords: hydrogen; composite cylinders; aluminum; type3; high pressure

\section{1. はじめに 〜社会的動向〜}

水素社会は,

（1）水素が燃焼時に二酸化炭素を排出せずクリーンなエネル ギーであること

（2）水素がいろいろな物から生成でき，エネルギーセキュリ ティーに優れていること

（3）日本の国際競争力を維持するうえで有益なこと など様々な観点から大きな期待が寄せられている。

2013 年 6 月に閣議決定された日本再興戦略においても 「2015年の燃料電池自動車の市場投入に向けて，燃料電池自 動車や水素インフラに係る規制を見直すとともに，水素ス テーションの整備を支援することにより，世界最速の普及を 目指す」ことが明記された。燃料電池自動車普及のためには, 既存のガソリン自動車およびガソリンスタンドと同等の安全 性，利便性，経済性を有する燃料電池自動車および水素供給 インフラ（水素ステーション）の実現が必要である。高圧水 素を貯蔵するFRP容器は, この3つの要求に重大に影響する ものであり，極めて重要な製品である。本稿では，燃料電池 自動車用複合容器および水素ステーション用複合蓄圧器とし て期待される, タイプ 3 容器（炭素繊維・アルミニウムライ ナー複合容器）について紹介する。

\section{2. 製品の概要}

\section{1 高圧ガス容器の種類}

高圧ガス容器は, その構造により図1のタイプ1〜タイプ 4 に分類される。

水素ステーション等に利用される圧縮水素蓄圧器用複合圧 力容器としては, タイプ 1 容器, タイプ 3 容器, タイプ 4 容 器が使用され, 燃料電池自動車等に利用される圧縮水素自動 車燃料装置用容器としては, タイプ 3 容器, タイプ 4 容器が 使用される。

タイプ1容器：金属製の継目なし容器である。長い安全の 歴史があるが，4種類の容器の中では最も重い。強度・コス 卜の面から，鉄鋼材料が用いられる場合が多い。
タイプ 2 容器: タイプ 1 容器を軽量化する目的で, 薄肉化 した金属製の継目なし容器（ライナー）の胴部に, 高強度の 繊維を周方向に巻いて強化（FRP）した容器である。タイプ 1 容器に対し，質量を $2 / 3$ 程度にまで軽量化できる。
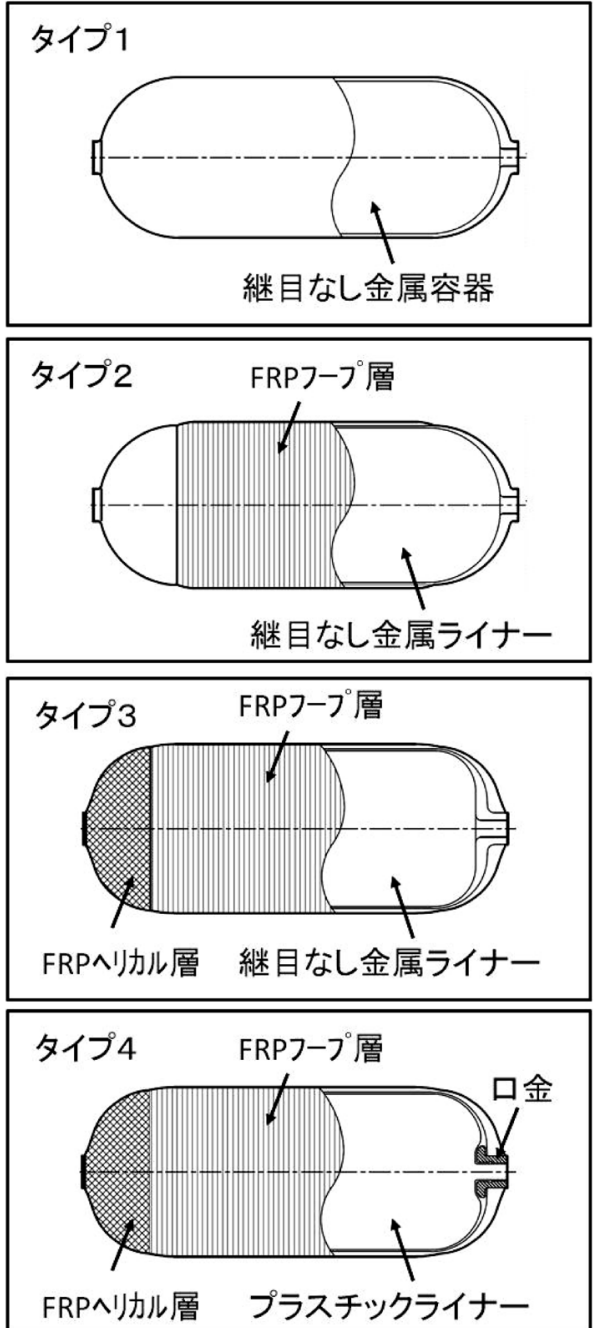

図 1 高圧ガス容器の種類

*サムテック株式会社＼cjkstart高圧ガス容器部（テ 582-0027大阪府柏原市円明町 1000番 18） SAMTECH Corp. (1000-18 Enmyo-cho, Kashiwara-shi, Osaka 582-0027) E-mail: senta_tojo@samtech.co.jp

受付日：平成 28 年 12 月 26 日 受理日：平成29年 2 月 14 日 
タイプ 3 容器：タイプ 2 容器よりもさらに薄肉化された金 属ライナーの胴部およびドーム部に, 高強度繊維を周方向 および軸方向に巻いて強化（FRP）した容器である。タイプ 1 容器に対し，質量を $1 / 3 \sim 1 / 5$ 程度にまで軽量化できる。軽 量化を目的とする場合には, ライナー材料にアルミニウム合 金が使用されることが多い。圧縮水素自動車燃料装置用容 器では, 金属ライナーの材質は6061-T6アルミニウムおよび SUS316Lステンレス, 高強度繊維の材質は炭素繊維 (CFRP) に限定される。

タイプ4容器：ライナー材料に熱可塑性樹脂, 口金部に金 属を使用し，タイプ 3 容器と同様にライナーの胴部および ドーム部に, 高強度繊維を周方向および軸方向に巻いて強 化 (FRP) した容器である。タイプ1容器に対し, 質量を $1 / 3$ $1 / 5$ 程度にまで軽量化できる。

表 1 米国におけるFRP容器の研究開発

\begin{tabular}{|c|c|}
\hline 1947 年 & 航空機用圧力容器の開発に着手 \\
\hline 1966年 & $\begin{array}{l}\text { NASA から FRP 複合容器の計算プログラム } \\
\text { CR-72124発行 }\end{array}$ \\
\hline 1970 年 & $\begin{array}{l}\text { NASAにより民生用FRP複合容器の開発が始 } \\
\text { まる }\end{array}$ \\
\hline 1976年 & $\begin{array}{l}\text { 米国DOTによる最初の民生用 FRP 複合容器 } \\
\text { が認可される }\end{array}$ \\
\hline 1981 年 & 米国DOT FRP-1 基準発行 \\
\hline 1982 年 & 米国DOT FRP-2 基準発行 \\
\hline $\begin{array}{l}1980 \text { 年代 } \\
\text { 後半から }\end{array}$ & $\begin{array}{l}\text { 天然ガス自動車燃料装置容器として注目され } \\
\text { る }\end{array}$ \\
\hline 1992 年 & ANSI/AGA NGV2 基準発行 \\
\hline
\end{tabular}

表2 日本におけるFRP容器の研究開発

\begin{tabular}{|c|c|}
\hline 1965 年以降 & 航空宇宙用容器の開発 \\
\hline 1982 年 & 最初の民生用空気呼吸器用容器の特別認可 \\
\hline 1985 年 & $\begin{array}{l}\text { 高圧ガス保安協会において軽量容器の研究 } \\
\text { 開発が始まる }\end{array}$ \\
\hline 1987 年 & $\begin{array}{l}\text { 米国から特別認可による空気呼吸器用容器 } \\
\text { の輸入が始まる }\end{array}$ \\
\hline 1990 年 & 最初のCNG 自動車用FRP複合容器の特別認可 \\
\hline 1997 年 & 特別認可から一般基準化 \\
\hline
\end{tabular}

\section{2 FRP容器の歴史}

FRP容器は 1947 年に米国の航空宇宙用容器として開発さ れ（表1），現在ではさまざまな分野で利用されるようになっ た。その1つとして，1980年代後半に地球温暖化防止の観点 から天然ガス自動車然料装置容器として注目されるように なった。

一方，我が国においては，1965 年から同じく航空宇宙用 容器として利用され始めた。民生用の容器としては, 1982 年に空気呼吸器用容器が最初の特別認可を受け, 1997 年か ら FRP容器の一部が一般基準化された (表 2$)^{1}$ 。

\section{3 適用例}

タイプ3容器 (炭素繊維・アルミニウムライナー複合容器) は, 後述する安全面から長期大量貯蔵に優れた特性を有して いる。よって, 図2に示すように, 水素ステーション用複合 蓄圧器や水素トレーラー用容器として使用されている。ま た, 国内の燃料電池自動車用容器としても採用されている。

\section{3. 材料要求特性}

\section{1 アルミニウム合金}

アルミニウム合金の材料特性としては疲労強度と耐水素 性・耐食性が重要になる。高圧ガス容器は, 高圧ガスの充 填と解放が繰り返されるため, アルミニウムライナーには 大きな応力振幅が 5,000回から 100,000回も繰り返される。 したがって, 疲労強度が高い材料を使用するほど炭素繊維 量（CFRP量）を低減することができ，コストを下げること ができる。疲労強度は引張強度に比例するため, 高い引張強 度の材料を探してもよいことになる（図3，表3）。

現在, 法令で認められているアルミニウム合金は6061材 のみであるが，今後は耐水素性・耐食性に優れた高強度なア ルミニウム合金の適用が求められている。

\section{2 炭素繊維}

炭素繊維の材料特性としては引張強度と縦弾性係数が重要 になる。炭素繊維の引張強度は耐圧性能に, 縦弾性係数は疲 労性能に大きく影響する（図 3，表4）。

炭素繊維の引張強度は耐圧性能に直接寄与する。よって, 引張強度が高い炭素繊維ほど, その厚さを薄くすることがで きる。炭素繊維の縦弾性係数は疲労性能に間接的に寄与す る。アルミニウムライナーのひずみ量は炭素繊維の縦弾性係 数で決まり, 炭素繊維の縦弾性係数が大きいほど（硬いほど） アルミニウムライナーはひずみにくくなる。したがって，炭

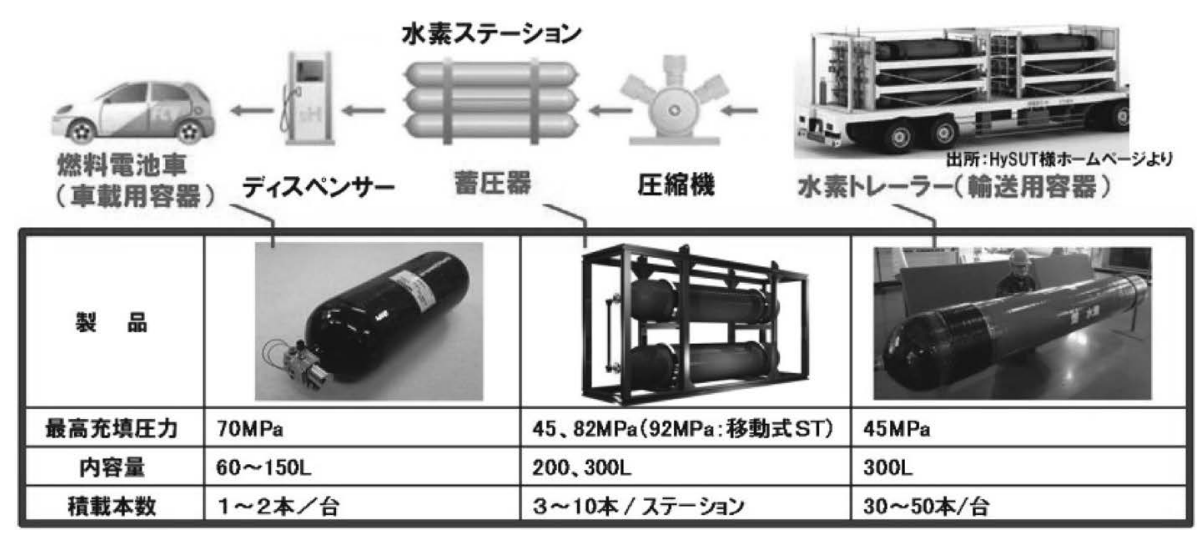

図2タイプ3容器の適用例 


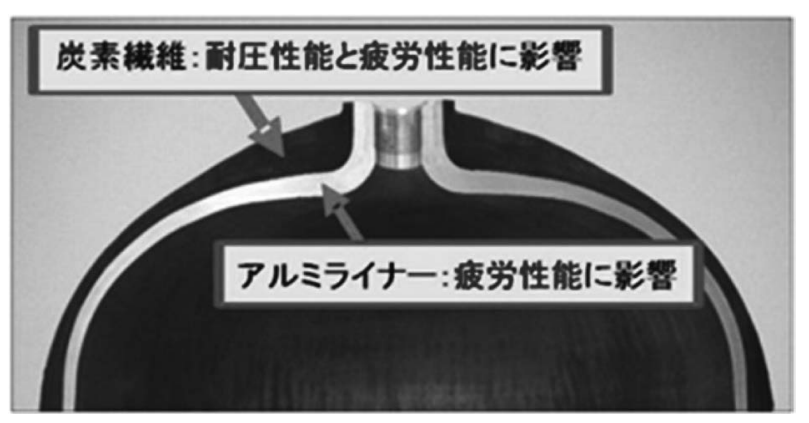

図3 タイプ3容器に求められる材料特性

表3 アルミニウムライナーに求められる材料特性

\begin{tabular}{l|l}
\hline \hline \multirow{3}{*}{ 引張強度 } & \multicolumn{1}{|c}{ アルミニウムライナー } \\
& $\begin{array}{l}\text { 疲労性能に強度と } \\
\text { その厚さが直接寄与 } \\
(\because \text { 引張強度 } \propto \text { 疲労強度 })\end{array}$ \\
\hline \multirow{2}{*}{ 縦断性係数 } & $\begin{array}{l}\text { 各種アルミニウム材で值がほぼ同じ } \\
\text { 影響は小さい }\end{array}$ \\
\hline
\end{tabular}

表4 炭素繊維に求められる材料特性

\begin{tabular}{|c|c|c|}
\hline & \multicolumn{2}{|c|}{ 炭素繊維 } \\
\hline 引張強度 & $\begin{array}{l}\text { 耐圧性能に強度と } \\
\text { その厚さが直接寄与 }\end{array}$ & 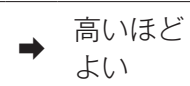 \\
\hline 縦断性係数 & $\begin{array}{l}\text { アルミニウムライナ } \\
\text { 炭素繊維の縦断性係 } \\
\text { 間接的にアルミニ } \\
\text { (疲労性能) を決定す }\end{array}$ & $\begin{array}{l}\text { み量は } \\
\text { るため, } \\
\text { 一の応力振幅 } \\
\text { 上きいほどよい }\end{array}$ \\
\hline
\end{tabular}

素纎維の縦弾性係数が大きいほどアルミニウムライナーの応 力振幅も小さくなり容器の寿命が長くなる。

\section{4. 製造工程}

タイプ3容器の製造工程について, 水素ステーション用複 合蓄圧器を例に説明する。工程は主に,
(1) ライナー製造
(1)スピニング加工
(2)熱処理
(3)ねじ切り加工

(2) 容器製造
(1)ワインディング
(2)樹脂硬化
(3)自緊処理

の6つの工程で製造される。

(1) (1)スピニング加工

受入れ検査を合格したアルミニウム押出管の両端部を，ス ピニング加工によりドーム形状に成形する（図4）。

加工はアルミニウム管を加熱後, 回転するアルミニウム管 にローラーを少しずつ押し当てながら変形させていく。内型 がなくローラーを一気に移動させるとアルミニウム管が座屈 するため, このローラーの動きをいかに制御するかが大変重 要になる。

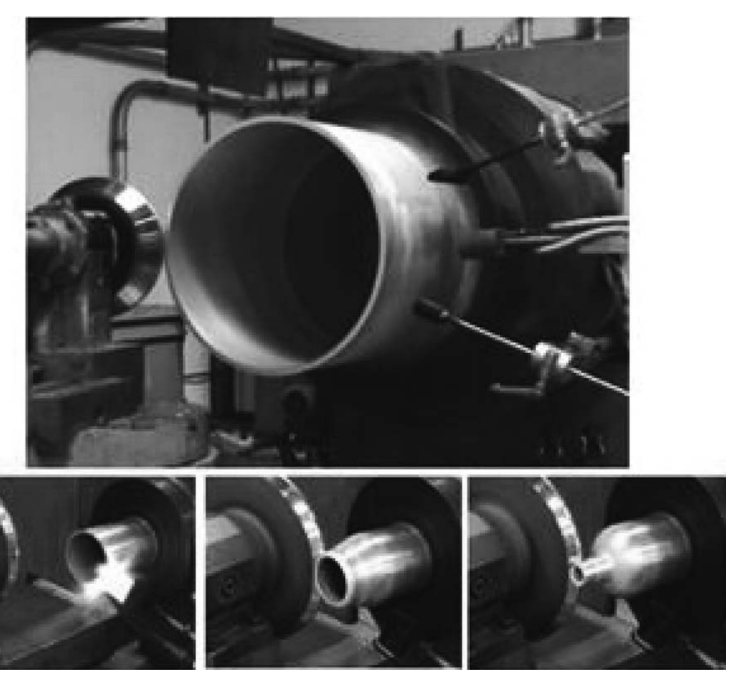

図4 スピニング加工

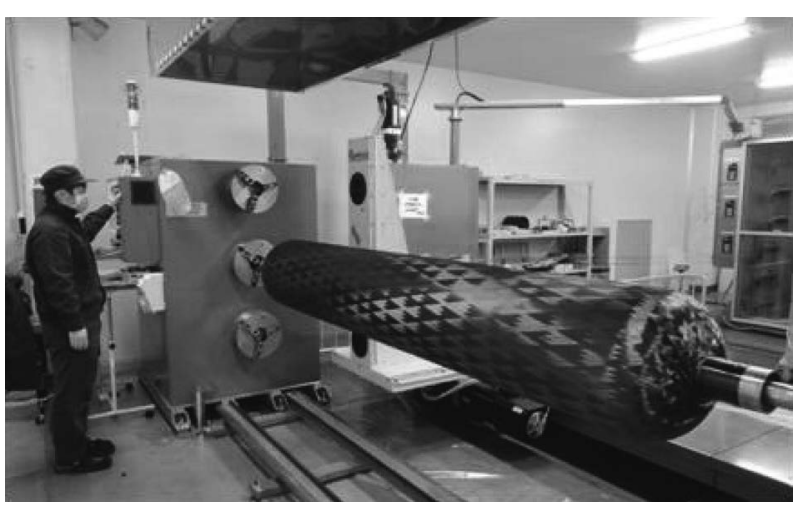

図 5 複合蓄圧器のワインディング風景

\section{(1) (2)熱処理}

両端部をスピニング加工されたアルミニウム管（ライ ナー）の T6熱処理を行う。熱処理によってライナーの機械 的性質が設計保証值以上になっていることを, 同一バッチか ら準備されたテストピースの引張試験により確認する。

(1) (3)ねじ切り加工

熱処理後のライナーの両端部 (ポート部) のねじ切り加工 を行う。

(2) (1)ワインディング

ライナーに熱硬化性樹脂を含浸させた炭素繊維を巻きつけ る。ライナーの周方向に巻きつけるフープ巻きと, 軸方向に 巻きつけるへリカル巻きを複数回繰り返すことにより，ライ ナー全体を炭素繊維で覆う（図 5)。

これが, タイプ3容器（およびタイプ4容器）がフルラッ プ構造と言われる理由である。

(2) (2)樹脂硬化

ワインディングされた容器を炉に入れて，樹脂硬化を行う。 (2) (3)自緊処理

容器内側のアルミニウムライナーに, 残留圧縮応力を付与 する自緊処理を行う。自緊処理は, 樹脂硬化後の容器にアル ミニウムライナーが塑性変形をするまで内圧を加えることに より行う。

この自緊処理により, タイプ 3 容器の疲労性能を向上させ ることができる。 


\section{5. 安 全 性}

\section{1 水素ガス}

まず，水素ガスの安全性について述べる。

水素ガスは空気拡散性が高いため, その性質を利用すれば 安全に使用することができる。その例を図6に示す ${ }^{2)}$ 。

図 6 は水素エネルギー製品研究試験センターの高圧水素試 験室の構造を示したものである。屋根には片側傾斜構造が取 り入れられ，最上部には大気中への拡散密が設けられている。 水素ガスは空気より軽く, 空気拡散性が高いため, 万が一漏 れが発生した場合にも直ちに拡散空から大気中に解放される。

このように水素ガスは正しい使い方をすれば，ガソリンや 都市ガス並みに安全なエネルギーである。

\section{2 タイプ3容器}

次に, タイプ3容器の安全性について述べる。

高圧水素ガス貯蔵において, 安全上重要なことは

（1）容器の破裂を未然に防ぐこと

(2) 水素ガスを外に漏らさないこと

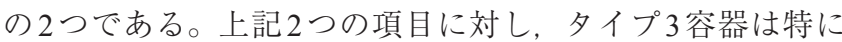
優れた機能を有している。

5.2 .1 容器の破裂を未然に防ぐ

タイプ3容器の構造を図7に示す。

タイプ 3 容器の多くは内側が高圧水素ガスをバリアするア ルミニウムライナー，外側がアルミニウムライナーを補強し 荷重の大部分を負担するCFRP層（炭素繊維強化プラスチッ ク）からなる。

容器の破裂を未然に防ぐ機能（L.B.B. 機能：Leak Before

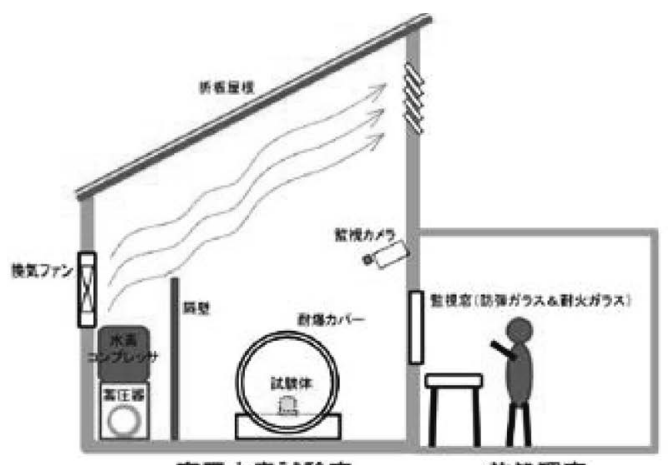

高圧水素試覧室

荡赵理室

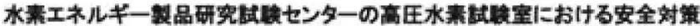

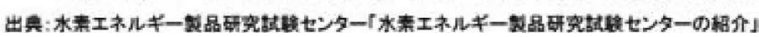

図6 水素エネルギー製品研究試験センターの試験室

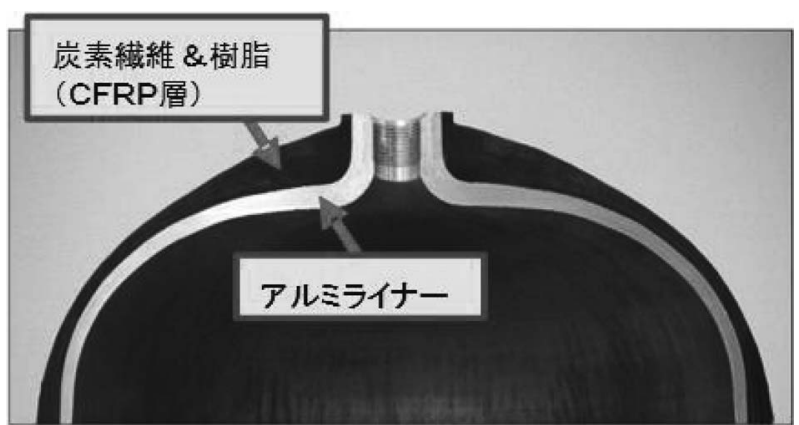

図7 タイプ3容器の構造
Burst）は，アルミニウムライナーの疲労強度がCFRPの疲労 強度より小さいことを利用し設計することができる。つま り，外部から何らかの衝撃を受けた場合や，設計以上の繰り 返し荷重を受けた場合にも，CFRP層の安全率を高くとるこ とにより，CFRP層がアルミニウムライナーより先に破断亦 ることなく破裂を防ぐことができる。言いかえれば，アルミ ニウムライナー内に先に疲労による小さな穴を進展させるこ とにより，容器の破裂以前にガスを少しずつ逃がす設計が可 能となる。また，CFRP層のさらに外側の最外層に，プロテ クト層としてのGFRP層（ガラス繊維強化プラスチック）を 形成することにより，CFRP層自体にもきずがつきにくい構 造とすることができる。

\section{2 .2 水素ガスを外に漏らさない}

貯蔵する水素ガスを外に漏らさないためには，ライナー材 料がもつガスバリア性（ガス透過率）が重要となる。一般的 に水素ガスに拐いて，金属材料のガス透過率は樹脂材料のガ ス透過率の $1 / 100$ 以下である ${ }^{3)}$ ため, タイプ 1 容器やタイプ 3 容器は長期貯蔵や大量貯蔵に有効である。

しかし, 近年タイプ4容器の中には, 樹脂ライナーに特別なガ スバリア層を設けて水素ガスの透過を抑制しているものもある。

\section{6. 課題と今後の期待}

\section{1 水素ステーションコストの低減に向けて}

ここまで例にあげた水素ステーション用複合蓄圧器は、コ ス卜的にも有利とされ，日本の水素ステーション（移動式を 含む）の70か所以上に採用された。しかし，2015年現在水 素ステーションの建設コストは 4 5 億円とも言われている。 FCCJのシナリオ (図8 ${ }^{4)}$ 通りに水素ステーションを建設し ていくためには建設コスト目標を 1 ～億円に抑える必要が あり，これが課題となる。

そこで水素ステーションコストの低減に向け，有効と思わ れるコスト低減策を以下に述べる。

(1) ステーション関連

(1)複合蓄圧器による基礎工事および保持部材の簡素化

(2)複合蓄圧器による設置スペースの低減

(3)複合蓄圧器を用いてのモジュール化による設計費および 現地工事費の低減

(2) 蓄圧器関連

(1) 高強度アルミニウムライナーによる CFRP材料の削減

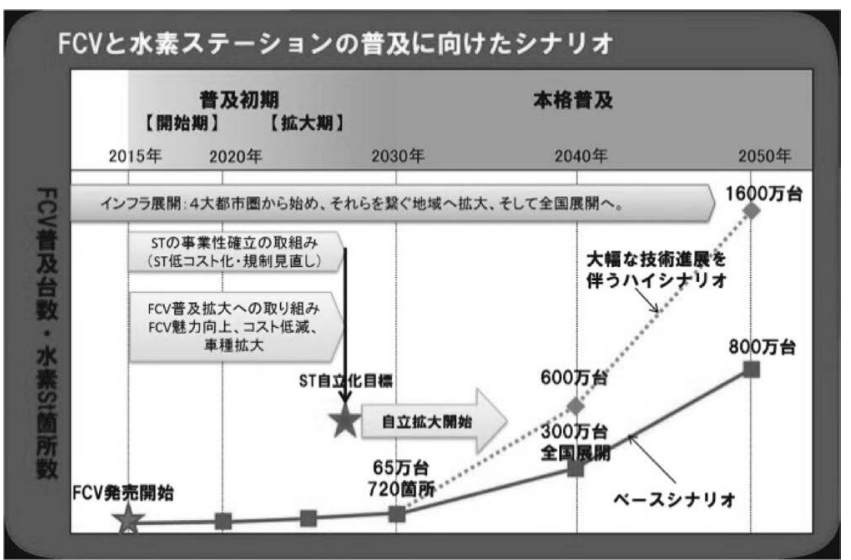

図8 F C V と水素ステーションの普及に向けたシナリオ4 
(1) (1)複合蓄圧器による基礎工事および保持部材の簡素化

$82 \mathrm{MPa}$ 以上対応の複合蓄圧器〔300 L 仕様： $725 \mathrm{~kg} 〕$ は鋼 製蓄圧器に比べると，重量が約 $1 / 5$ 程になる。これはアルミ ニウム合金の比重が鋼の比重の約 $1 / 3$ であること，炭素繊維 の引張強度が鋼の引張強度の約 10 倍であることによる。

この複合蓄圧器の軽量特性は, ステーション建設における 蓄圧器設置場所の基礎工事の簡素化および蓄圧器搭載ラッ ク（図9）の簡素化に寄与する。

(1) (2)複合蓄圧器による設置スペースの低減

複合蓄圧器の軽量特性は, 設置場所にも様々な自由度を与 える。具体的には, 複合蓄圧器の水素ステーションのキャノ ピー（屋根）上への設置である。

アメリカではLos Angeles でICC 水素規制に準拠したもの が実用化（図 10）されているが，日本でも実用化されれば 都市部等の敷地が狭いステーションのスペース削減に大いに 有効と考えられる。

(1) (3)複合蓄圧器を用いてのモジュール化による設計費お よび現地工事費の低減

水素ステーションの建設コスト低減のためには，各機器 のコスト低減とともに, 総コストの $47 \%$ を占める現地工事 費，設計費の低減が重要である。複合蓄圧器は軽量であるた めに，図9のように工場でより大きな単位（ユニット）にま で組上げた状態で現地に運ぶことができ，現地工事の簡素化

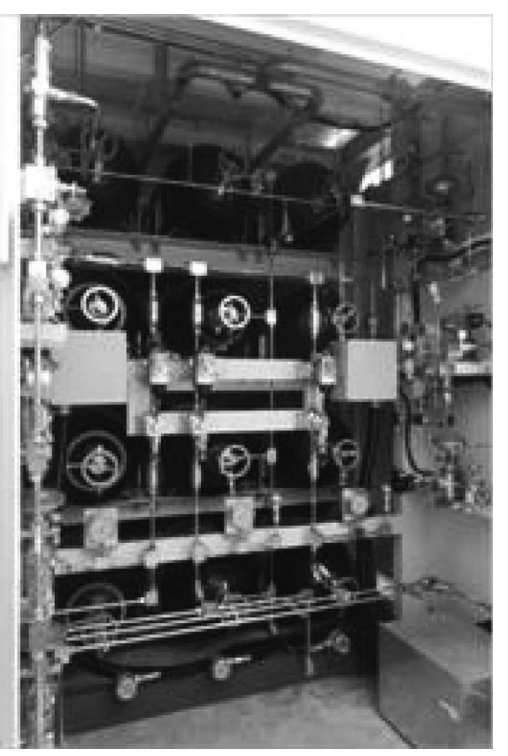

図 9 複合蓄圧器の搭載ラック

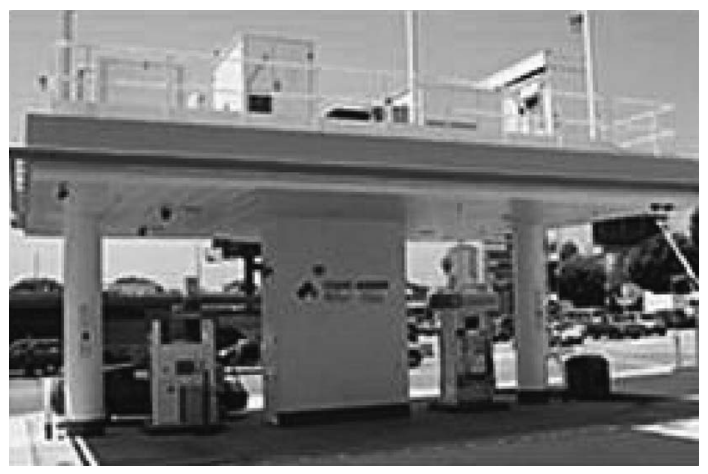

図10 キャノピー上に蓄圧器が設置された例 ${ }^{5)}$
に貢献する。また，軽量であるために，現地での基礎工事も 簡素化できる。さらに，このようなユニットを標準化するこ とによって, 設計費 ${ }^{6)}$ の低減にも貢献できると考えられる。 こうした考えは，欧米の自動車会社がコストダウンの決め手 として推進しているモジュール化と同様であるが, 軽量な複 合蓄圧器を用いることにより実現が可能である。

(2) (1)高強度アルミニウムライナーによるCFRP材料の削 減

アルミニウムライナー材料に高強度なアルミニウム合金を 使用すると，CFRP層の厚さを低減できる。

CFRP層を構成する炭素繊維は，材料コストの半分以上を 占めるためコスト低減に大変有効である。アルミニウムライ ナーには耐水素性も求められるため, 設計的検証と材料的検 証を並行して行う必要がある。しかし，蓄圧器本体のコスト 低減とさらなる軽量化が同時に達成できるため, 大変魅力的 なコスト低減策である。有望な材料として，7000系アルミ ニウム合金が挙げられる。

\section{7. おわりに}

〜水素社会における複合容器の可能性〜

2 章で述べたように，燃料電池自動車のほかにも水素社会 は様々な可能性を秘めている。その1つが再生可能エネル ギーの有効利用である。

最近，太陽光や風力といった自然エネルギー発電は増加の 傾向をみせているが本格的な普及までにはまだ時間がかかる と感じられる。その理由として，(1)投資コストを回収するま でに歳月を要すること, (2)安定的に電力が得られないこと, などが挙げられる。

その弱点をカバーするアイテムとして水素ガスの高圧貯蔵 が注目されている。それは，太陽光や風力といった自然エネ ルギー発電の余剩時の電力を, 水の電気分解等により水素の 形で蓄圧器等に貯蔵し, 必要な時に発電して使うものであ る(図11)。

電力を貯蔵する方法としては，バッテリーによる蓄電も考 えられるが, バッテリーには漏電といった問題があるため, 長期貯蔵には向いていない。しかも, 貯蔵する電力量に比例 してコストや体積が増大するため, 大量のエネルギーを貯め るのに向いていない7)。

それに対し, 高圧水素ガスという形で水素をタイプ 3 複合

再生可能エネルギーの有効利用

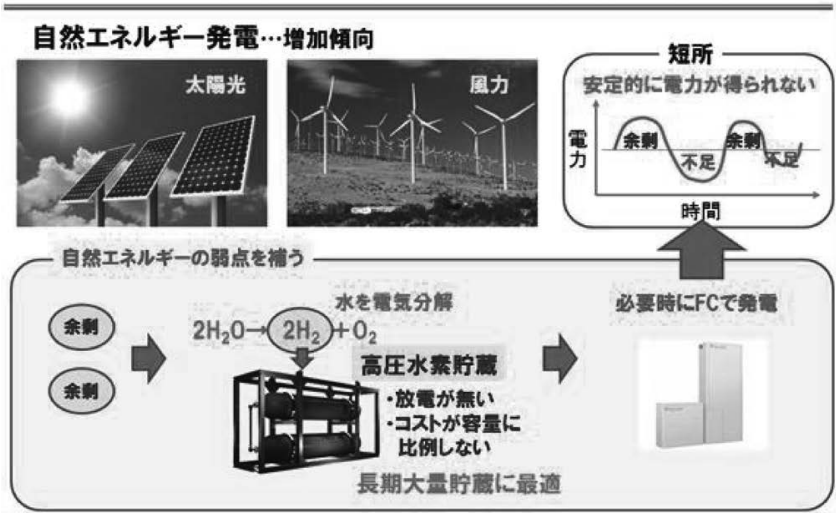

図11 複合蓄圧器による再生可能エネルギーの有効利用 
蓄圧器に貯蔵すれば，水素の透過がほとんどないため大量の エネルギーを長期間貯めることができ，太陽光や風力といっ た自然エネルギー発電の弱点を補うことが可能となる。燃料 電池自動車の航続距離が長い理由は, この高圧水素ガス貯蔵 の利点を最大限に活用しているためと言える。

また, 高圧水素ガス貯蔵は燃料電池自動車や家庭用燃料電 池を介して災害時の非常用エネルギーとしても利用でき，水 素社会に扮ける複合容器の果たす役割は大きい。

以上のように，アルミニウム合金をライナー材料として用 いるタイプ3容器は, 水素容器として様々な可能性を秘めて いる。

\section{参 考 文 献}

1) 竹花立美：FRP複合容器の設計と安全性評価に関する研究, 博
士論文, 東京都立大学, (2000), 4-6.

2) 菊川重紀: 水素エネルギー製品研究試験センターの紹介, 燃料 電池, 10(1) (2010), 160-165.

3) 財団法人日本自動車研究所:「水素安全利用等基盤技術開発」車両関連機器に関する研究開発—燃料電池自動車に倸る安全技 術研究 平成 15 年度 16 年度成果報告書, 60 .

4) 燃料電池実用化推進協議会 (FCCJ)：FCV と水素ステーション の普及に向けたシナリオ，(2016.3）

5) Fuel Cell \& Hydrogen Energy Association ホーム ページ, http:// www.hydrogenandfuelcellsafety.info/2008/aug/shellStation.asp

6) 一般財団法人石油エネルギー技術センターほか：70 MPa 級水 素ガス充填対応ステーション機器システム技術に関する研究開 発 (平成 20 年度 24 年度成果報告書), 独立行政法人新エネル ギー・産業技術総合開発機構, (2013), 376.

7) 本田國昭：ハイドリズム4，株式会社ガスレビュー，(2013.9）, $8-9$. 